\title{
Luhmann - Protreptikos pros theologous
}

Jaroslav Vokoun

Zatímco se v českém teologickém diskursu celkem běžně setkáme se jménem Derridovým, stranou zájmu stále zůstává jeho současník Niklas Luhmann, jehož s Derridou spojuje kritický vztah k evropské metafyzické tradici, ale svým konstruktivistickým programem představuje alternativu k dekonstrukci. ${ }^{1}$ Je ovšem čas bořit, a v tom se lze opřít o Derridu, je však také čas stavět, a zde je mnohem lepším rádcem Luhmann. Budova současného evropského křestanství je ve stavu, kdy se klade otázka, zda zbourat, nebo zrekonstruovat - mým teologickým rozhodnutím je to druhé. Na jiném místě jsem načrtl program rekonstruktivní teologie ${ }^{2}$ a zde bych jej rád - v návaznosti na diskuse, které se vedly v mé a o něco starší generaci - spojil s metodologií, která si - vzdor své intelektuální náročnosti, nesrovnatelné s nesnesitelnou lehkostí poststrukturalistické

1 Ke vztahu Luhmannova a Derridova díla srov. G. Тномаs - A. Scнüle (ed.), Luhmann und die Theologie, Darmstadt: Wissenschaftliche Buchgesellschaft, 2006, s. 93-103. Jiným, $\mathrm{v}$ českém prostředí již poněkud recipovanějším autorem, s nímž se Luhmann průběžně vyrovnával jako se základní alternativou, je Habermas. Výtka Habermasových stoupenců vůči Luhmannovi je obdobná jako u stoupenců Derridových, tj. že Luhmann stabilizuje systém, kdežto oni ho bourají, a tím osvobozují ty, kdo byli ze systému vyloučeni. Habermasovou alternativou je konsensuální racionální komunikace. Luhmann kontruje např. takto: „Všechny tyto teorie rozumu a subjektivity za sebou vlečou temnou stránku, která zahaluje to, co by člověk uviděl, kdyby se zeptal, co že se stane s těmi, kdo jsou nerozumní. Ty je možno odsunout do nějakých azylů, věznic, označit za nemocné. (...) Ale to jsou, jak je vidět, vždy jen částečné pomocné prostředky vzhledem ke skutečnosti, že empatický dưraz na rozum bude mít vždycky problém, co dělat, když někdo partout nechápe to, co my sami považujeme za rozumné - problém, který má i Habermas, když se dojde k rozumnému konsensu a pak tu ještě někdo je, kdo to nechápe - ano, co s ním uděláme?" (N. LuhmanN, Einführung in die Theorie der Gesellschaft, Heidelberg: Carl-Auer-Systeme-Verl., 2009, s. 322.). K obavám poststrukturalistů a teoretiků komunikativního jednání ze systémů lze asi stručně říci, že univerzální systém nemusí být nutně totalitní, protože můžeme mít, a obvykle i s užitkem máme, několik univerzálních systémů (které se ovšem vzájemně kritizují a relativizují). Nebezpečná je totalizace a dogmatizace jediného universálního systému - jako takový systém ovšem může fungovat i poststrukturalismus či komunikativní konsensus; bojovníci proti vylučování také mnohé vylučují.

2 J. Voкоun, Krekonstrukci teologie po konci novověku: postkritický př́stup, České Budějovice: Jihočeská univerzita, 2008. 
argumentace - postupně razí cestu do společenských věd a také do teologie.

\section{LUHMANNOVY PROVOKACE TEOLOGŮ}

Mezi tvůrci velkých metodologických koncepcí dvacátého století patřil Niklas Luhmann k nemnohým, kteří vůbec registrovali existenci teologie ${ }^{3}$ či dokonce hledali dialog $\mathrm{s}$ teology. ${ }^{4}$ Luhmannův vztah $\mathrm{k}$ teologům byl provokativní $\mathrm{v}$ obou emocionálních významech toho slova - na jedné straně provokoval teology ironiemi a jedovatostmi, jednostranným nálepkováním určitých teologických strategií a závěrů, na druhé straně se při svém sociologickém Fremdbeschreibung teologie často tak ztotožnil s předmětem popisu, že např. jeho popis úkolu teologie „zvnějšku“ je mnohem lepší než nejedno naše teologické Selbstbeschreibung téhož; a najdeme u Luhmanna místa, kde jako teolog upřímně lituji, že jsem to nenapsal sám, např. když Luhmann v analýze možného místa „transcendence“ v dnešní společnosti říká: „Přijetí vyloučení (Exklusion) beze ztráty př́iklonu ke světu se může jevit sociologicky, jakož i psychologicky jako ve vysoké míře nemožné (implausibel). Ale pak by snad mohl něco znamenat odkaz na to, že už to přinejmenším $v$ jednom exemplárním př́ípadě bylo možné: v případě Ježíše z Nazareta. “5

3 Např. jen tak mimochodem v textu na téma zcela neteologické: „I pro zobrazování společnosti v médiích zřejmě platí, že známá a viditelná selekce skutečností a mínění zakrývá, že svět není jen ,a tak dále' ještě dalších skutečností a ještě dalších mínění, ale, jak by teologové řekli o Bohu, něčím zcela jiným." (N. Luhmann, Die Gesellschaft der Gesellschaft, Frankfurt am Main: Suhrkamp, 1997, s. 1111.). Nebo jinde v proudu výkladu: „Teologové se budou patrně ptát, jakou má teorie diferenciace prostřednictvím kódování užitnou hodnotu“" (N. LummanN, Gesellschaftsstruktur und Semantik: Studien zur Wissenssoziologie der modernen Gesellschaft 3, Frankfurt am Main: Suhrkamp, 1989, s. 353.). Zcela bez ironie $\mathrm{k}$ teologii je zřejmě míněna i tato vtipná poznámka na okraj: „Takovéto formulace (= ,distinctio est indistinctio‘ Mikuláše Kusánského, pozn. J. V.) mají v teologii tradici. Kdyby chtěla neokybernetika zkoumat své předchůdce, musela by je tedy hledat spíše v teologii než v epistemologii“ (N. Luhmann, Die Wissenschaft der Gesellschaft, Frankfurt am Main: Suhrkamp, 1992, s. 88.).

4 Tak např. předmluvu ke knize Funktion der Religion (N. LuHmann, Funktion der Religion, Frankfurt am Main: Suhrkamp, 1977) končí Luhmann slovy: „Především jsem v napětí, zda teze, že náboženství pro společnost plní centrální a současně velmi specifickou funkci, a sice na základě určitého historického vývoje, se může pro teology stát základem rozhovoru."

5 Luhmann, Gesellschaftsstruktur und Semantik, s. 340. 
Přehled teologického navázání na Luhmanna podal ve své disertaci z r. 1988 Dallmann; ${ }^{6}$ z Luhmannovy poznámky z r. 1989 (tedy před knižním vydáním zmíněné práce) je patrná Luhmannova skepse vưči praktickým možnostem sociologicko-teologického dialogu o jeho díle s ohledem na dosavadní výsledky. ${ }^{7} \mathrm{~S}$ odkazem na Dallmannovu studii a na přehled dovedený až do současnosti Blankem ${ }^{8}$ není cílem této práce podat systematický přehled Luhmannovy teorie z teologického hlediska ani teologického navázání na Luhmanna, ale předložit k české diskusi některé podněty, které lze z Luhmannových spisů a z teologických reakcí na ně vyvodit jako potenciálně relevantní pro české prostředí.

\section{Kř̌sŤANSTVí JAKO NÁBOŽENSTVÍ?}

Kritika pojetí křestanství jako jednoho z náboženství a teologická kritika "klasického“ theismu ${ }^{9}$ byly jednou z mála velkých diskusí, které se v českém evangelickém prostředí 2. pol. 20. stol. vedly, a sice $\mathrm{v}$ rámci recepce Bonhoeffera a jako ozvěna zejména německé diskuse, ale zprostředkovaně i amerických debat o „Boží smrti“ (a také autor tohoto článku se s teologií setkal poprvé v tomto kontextu a samizdatově do zmíněné diskuse - spíše popularizačně - počátkem osmdesátých let vstupoval). Tato diskuse stále ještě latentně ovlivňuje české evangelické prostředí, od iritace čerstvých adeptů teologie po iritace veřejného prostoru výroky některých evangelických farářo o tom, že jejich úkolem je boj proti náboženství...

Chceme-li se s Luhmannem teologicky vyrovnávat, budeme muset ovšem zmíněnou problematiku znovu promyslet, $\mathrm{k}$ čemuž je ostatně i řada jiných důvodů - tehdejší diskuse se dělala v kontextu optimistického ateismu a feuerbachovské kritiky, psychologicky pod tlakem

6 H.-U. Dallmann, Die Systemtheorie Niklas Luhmanns und ihre theologische Rezeption, Stuttgart: W. Kohlhammer, 1994. Dalmannovy výklady o jednotlivých autorech (např. Herms, Pannenberg, Rendtorf, Wagner) jsou ovšem poměrně stručné, spíše hodnotící než informující a reflektují zejména navázání na téma Sinnfrage z prvního Luhmannova spisu o náboženství.

7 LuHmann, Gesellschaftsstruktur und Semantik, s. 351.

8 E. BlanKe, Systemtheoretische Beobachtungen der Theologie, Marburg: Tectum-Verl., 2012, S. 54-62.

9 Klasickým theismem byl v těchto diskusích zpravidla míněn theismus novověké filosofie, nikoli scholastické výklady o Bohu. 
konceptu sekularizace; dnes je ji třeba vést v kontextu tlaku světových náboženství na evropské prostředí, přičemž mladší teologická generace vnímá pojem náboženství zjevně mnohem pozitivněji; také Bonhoeffer byl mezitím objeven jako spíše konzervativní teolog (pamětníci si vzpomenou, jak zarážející kdysi bylo uveřejnění jeho svatebního kázání $\mathrm{z}$ „,kultovní“ korespondence z vězení v KR).

Přehodnocením tehdejší diskuse vůbec nemyslím, že by bylo třeba ji zavrhnout; zcela naopak, budeme ji ještě potřebovat $\mathrm{k}$ tomu, abychom Luhmanna mohli přijmout kriticky kreativně. Pouze budeme muset vzít na vědomí, že koncept sekularizace vidí Luhmann z dobrých důvodů jako nepoužitelný a že $\mathrm{v}$ diferencované moderní společnosti můžeme operovat jen jako součást dílčího systému náboženství a být jako takoví identifikovatelní. To můžeme přijmout, či se proti tomu můžeme/musíme z motivů své teologie bouřit, nicméně je to naší výchozí pozicí. Ve společenské praxi se s dílčím systémem náboženství ž̌ejmě musíme do značné míry identifikovat a až $\mathrm{v}$ rámci této identifikace provádět odlišení - v systemické terminologii to lze formulovat asi takto: Společensky musíme být identifikovatelní jako součást systému náboženství, a poté, co jsme takto identifikováni, musíme být dále identifikovatelní jako subsystém, který se tomuto systému vymyká. Pokud nebude splněna první podmínka, budeme zaměněni se skupinami operujícími v jiných systémech (politika, ekonomika, ekologie, morálka), pokud nebude splněna druhá podmínka, budeme se svou zvěstí pacifikováni v mezích náboženského systému.

Především nám ovšem Luhmann umožňuje překonat jeden závažný problém diskuse sedmdesátých let. Nad tehdejšími texty se lze těžko ubránit dojmu, že jsou následným vysvětlením toho, proč je na tom křest’anství špatně a proč se s tím nedá nic dělat. Luhmann ovšem - zde stejně jako na mnoha jiných místech - perspektivu obrací: Náboženství se mu jeví jako společensky perspektivní systém - a právě z důvodů, které jsou naší tehdejší diskusi ${ }^{10}$ blízké: Náboženství, které se diferencovalo jako samostatný systém, už nemusí plnit společenské funkce, které plnilo před touto diferenciací, a konečně se může věnovat vlastnímu důvodu své existence, což by mělo znamenat jeho velký rozvoj. Převedeno na křestanství, konečně má po staletích možnost rozvíjet se jako křestanství, ne např. jako strážce morálky či ideologická opora režimů. To

10 Viz např. slogan o „překonání konstantinské éry“, což ovšem bylo také, historicky viděno, nepřípustné zjednodušení. 
znamená svobodu a samozřejmě pro mnohé i frustraci ze ztráty společenské funkce. Současná situace tedy nabízí především velké příležitosti, zatímco teologové a církevní stratégové v ní mají sklon vidět hlavně úpadek. Nad tuto aktuální souvislost ovšem vidí Luhmann náboženství jako konstantně pro společnost potřebné - i kdyby ho ten či onen člověk opravdu nepotřeboval. ${ }^{11}$

Otázka "křest’anství jako náboženství" se ovšem teologovi nad Luhmannem neustále vrací, nebot’ v mnohém z toho, co Luhmann ř́íká o náboženství, se jako křestan nepoznává, v jiném se naopak poznává, ale vidí to jako specificky křestanské až reformační, ${ }^{12}$ či jako příznačné jen pro semitská náboženství. Dospívá-li Luhmann postupně k tomu, že kódem náboženství je mluvit o transcendentním v imanenci, pak tím samozřejmě aktualizuje i bonhoefferovskou tradici, která nám v letech teologického a-teismu umožnila nacházet Boha, vyhnaného z nebes, v naší každodenní skutečnosti (a nově objevit christologii a speciálně inkarnaci, viz dále).

Zdá se mi, že v německé diskusi nad Luhmannem se tento diferencovaný prrístup k pojmu náboženství, a tím i k možnosti zahrnout křest̉anství do rámce toho, co Luhmann sděluje o náboženství obecně, projevuje velmi slabě, resp. zejména odmítáním Luhmanna jako takového. Rovněž v novější německé diskusi o sekularizaci, jíž jsem se zabýval jinde, ${ }^{13}$ se s Luhmannovým pojetím prakticky nepracovalo;, ${ }^{14}$ revize pohledu na sekularizaci se prováděla v návaznosti na Petera Bergera. Přitom Luhmann vidí nejen bezradnost náboženských představitelů nad „sekularizací", ale také to, že to, co je její podstatou, tedy diferenciaci z celku společnosti jakožto samostatný systém, provedlo náboženství dříve než

11 Luhmann, Gesellschaftsstruktur und Semantik, s. 349n. Toto tvrzení má ovšem v kontextu Luhmannovy koncepce společnosti bez subjektů specifický význam, nicméně pro církev znamená, že její společenský význam je dán tím, že se věnuje svému poslání, nikoli, že vymýšlí, jak být společensky „relevantni“".

12 Jako např. Luhmannův samožrejmý předpoklad, že „médium náboženství je víra“. To pak Luhmannovi umožňuje při popisu církevní organizace a jednání církevních grémií ukázat, že ta se dějí v jiném kódu než náboženském (ekonomickém či politickém, tj. témata peníze a moc), v př́ípadě některých církví se diskuse do kódu převede sakralizací organizace a jejích orgánů, srov. LuHmann, Funktion der Religion, s. 310nn. VoKoun, K rekonstrukci teologie po konci novověku: postkritický př́stup, s. 33-46.

Ostatně ani s Eisenstadtovým. Srov. S. N. Eisenstadt, Tradition, Wandel und Modernität, Frankfurt am Main: Suhrkamp, 1979. Ke změně paradigmatu modernizace zejména s. $128 \mathrm{nn}$. 
ostatní systémy a je tedy spouštědlem a protagonistou tohoto vývoje; ${ }^{15}$ stejně jako sehrálo podobnou roli v př́ípadě moderní individualizace subjektu, s níž si dnes obdobně neví rady.

$\mathrm{V}$ rámci někdejších diskusí o theismu je možné diskutovat i o Luhmannově pojetí Boha. Pro teologa může být sice pozoruhodné, že Luhmann jako agnostik potřebuje k plnosti svého systému Boha ${ }^{16}$ (kterého musí nutně předpokládat a současně odmítat), ale současně musí upozornit na to, že Luhmannův Beobachter-Gott není Bohem křestanství, ale typickým produktem theismu sedmnáctého století17 - Bůh, o němž kdysi řekl McIntyre, že si ho vzdělanci v sedmnáctém století vymysleli a v devatenáctém zjistili, že v něho nemohou věřit. ${ }^{18}$

\section{OteVŘenÁ círKeV?}

Z perspektivy druhé dekády druhého tisíciletí je patrné, že jsme ve dvacátém století jednostranně upřednostnili ekklesiologii a zanedbali jiné discipliny. Výtku z upřednostnění něčeho a zanedbání ostatního je ovšem možno obrátit proti kterékoli epoše; otázkou je, zda tato preference pro určitou disciplinu byla oprávněná či nikoli. ${ }^{19} \mathrm{~V}$ luhmannovské perspektivě se to jeví tak, že šlo o oprávněnou akcentuaci - po radikální diferenciaci systému církve z celku společnosti bylo nutno jasně tento

15 Nikoli tedy reakčním útvarem kulhajícím pozadu za dějinami, srov. LuHmann, Gesellschaftsstruktur und Semantik, s. 270.

16 „Otázka externího pozorovatele se tak vlastně neklade. Jeho starou formou byl pojem Boha". Lummann, Einführung in die Theorie der Gesellschaft, s. 288.

17 Což ovšem vůbec není „klasický theismus“ křestanské tradice, třebaže nám s ní v sedmdesátých letech splýval. Toto kritizuje např. B. OBERDORFER, „Kontingenzformel Gott," in Luhmann und die Theologie, ed. G. Thомаs - A. SснüLe, Darmstadt: Wissenschaftliche Buchgesellschaft, 2006, s. 110n.

18 Ještě jinou možnost navázání na Luhmannovu ranou sociologii náboženství ukazuje sborník příspěvků hodnotících současný reformní proces v EKD (,Kirche der Freiheit"). Luhmannovo široké pojetí náboženství a jeho významu pro společnost je zde zjevně př́ležitostí $\mathrm{k}$ obhajobě společenské role církve. Jakkoli v českém prostředí jsou problémy spíše opačné, neškodilo by patrně vzít jednou v úvahu, že by církev mohla mít celospolečenský př́nos, nikoli se spokojit s tím, že je tu sama pro sebe a své členy. Jsem si ovšem vědom složitosti této otázky. Ke zmíněné německé diskusi nad jedním Luhmannovým textem na téma organizovatelnosti náboženství viz J. Hermelink, Paradoxien kirchlicher Organisation Niklas Luhmanns frühe Kirchensoziologie und die aktuelle Reform der evangelischen Kirche, Würzburg: Ergon-Verl., 2008.

Stranou necháváme paušálnost tohoto hodnocení. 
systém vymezit, aby mohl být operativní, což v systemické teorii znamená především vymezit (tj. rozlišit, vést hranici), co je vlastní systém a co je jeho Umwelt - vnější prostředí, vytvořit sebepopis systému a uvést jej do vztahu k jeho popisům $z$ vnějšku, tj. z perspektivy systémů, pro něž je církev součástí jejich vnějšího prostředí; takovéto sebevymezení je nutně ekklesiocentrické, chybou je tento ekklesiocentrismus až v případě, kdy systém zapomene právě na to posledně zmíněné, tj. že tu jsou jiná centra, pro něž je on vnějším prostředím. Integrace církve do moderní společnosti je možná právě jako komunikace s těmito systémy, reakce na jejich systémové potřeby a defekty; zdá se, že stoupenci integrace do společnosti měli často na mysli společnost v nediferencovaném smyslu, která fakticky už neexistuje, pokud ovšem neměli na mysli integraci do dílčího systému politiky. Naproti tomu církve už většinou intuitivně pochopily, co je v diferencované společnosti jejich rizikem a šancí z hlediska systemické teorie: $\mathrm{Na}$ jednu stranu jsou spolu se systémem umění a zčásti i vědy systémem, do něhož se už nikdo nemusí integrovat, pokud nechce (narozdíl od politického, ekonomického a právního systému), na druhé straně se od ostatních systémů liší tím, že mohou bez problémů ignorovat exklusi jedinců z jiných systémů, která se jinak lavinovitě propojuje např́ic společenskými systémy (jedinec se dostane do ekonomické nouze a v důsledku to přivodí faktické vyloučení z participace na politickém, školském a právním systému atd.). Obrat od církve exkluzivní k církvi inkluzivní (od církve vylučující k církvi zvoucí) vidí Luhmann jako základní znak proměny církve v rámci moderní diferenciace systémů, ${ }^{20}$ přičemž nepřímo doporučuje církvím inkluzi jako strategii v míre, která by teologicky už znamenala synkretismus. ${ }^{21}$

Zaměření na ekklesiologii $\mathrm{v}$ posledním století bylo z praktických důvodů zřejmě odůvodněné, stejně jako byl na počátku tohoto procesu v pozdním středověku odůvodněný zrod ekklesiologie samotné, otázkou spíše je, zda se ekklesiologie pěstovala dobře, či špatně. To se může týkat i samotného tématu inkluze (viz dále o identitě a kódu), zde se však zastavíme u strategie zvoucí církve, která byla a ještě zřejmě je atraktivní vizí v podobě utopie "otevřené církve“. Podobně jako v př́ípadě př́istupu k otázce "křestanství jako náboženství" povede i zde vyrovnání $\mathrm{s}$ Luhmannem $\mathrm{k}$ diferencovanějšímu přístupu k tomuto modelu. Syste-

20 Srov. Luhmann, Gesellschaftsstruktur und Semantik, s. 327.

21 Luhmannovy př́klady jsou z latinskoamerického katolicismu. Srov. N. LuHmann, Die Religion der Gesellschaft, Frankfurt am Main: Suhrkamp, 2000, s. 351n. 
mická teorie se zrodila právě v opozici vưči modelu otevřených systémů. Funkční systém musí být "operativně uzavřený“, aby mohl přežít a reprodukovat se. Operativní uzavřenost neznamená model církve jako sekty, systém potřebuje pro přežití relativní otevřenost; operativní je takový model, kdy se systém na jedné straně uzavře zahlcení množstvím podnětů zvnějšku, na druhé straně si však dovede na základě kódu, tedy ve shodě se svou identitou vybírat $z$ vnějšího prostředí to, co potřebuje pro svůj růst, a také dokáže rozpoznat, co by mohl vnějšímu prostředí nabídnout. Tento model, at' už jej chápeme ontologicky, nebo metaforicky, je zřejmě ekklesiologicky přijatelný a realizovatelný. Jeden z teologů, reagujících na něj, formuluje "uzavřít se, abych mohl být otevřený". V každém př́ípadě ze systemické teorie plyne a z praxe určitých církví a skupin je patrné, že principiálně otevřený systém nemůže ani operovat, ani se reprodukovat.

Pokus aplikovat systemickou teorii na dějiny prvotní církve to zřejmě potvrdil. ${ }^{22}$ Oproti relativně otevřené církvi epochy apologetů (Justin) se církev o několik málo desetiletí později (Ireneus) v rozlišení vůči gnózi do značné míry uzavře, luhmannovsky formulováno „ztvrdne“ či „vyztuží se“, a to nejen ideově, ale i posílením formálních a institučních prvků - a gnostickou krizi přežije, zatímco gnóze v tehdejší podobě se rozplyne. ${ }^{23}$ Aby bylo dostatečně jasné: Není mým cílem propagovat model uzavřené církve, a soudím, že klasické vymezení křestanství je užší, než bylo teologicky nutné, a jednoznačnější, než je teologicky možné, nehledě na to, že ze systemické teorie plyne, že nedostatek neurčitosti také vede $\mathrm{k}$ zániku systémů či jejich převrácení v chaos. Z ekumenického hlediska lze paušálně říci, že problém evangelické církve a problém římskokatolické církve je dnes symetricky opačný. Otevřenost křestanství v určitých směrech je podle mého soudu ještě stále nedostatečná. ${ }^{24}$ Oč mi jde, je taková otevřenost/uzavřenost církve vnějšímu prostředí, která nepovede k ochromení křest’anství, ale ke skutečné výměně s prostředím,

22 Srov. J. E. Hafner, „Häresiefähigkeit: Die Systemwerdung des Frühchristentums als Medienereignis, in Luhmann und die Theologie," in Luhmann und die Theologie, ed. G. Тномаs - A. Scнüle, Darmstadt: Wissenschaftliche Buchgesellschaft, 2006, s. 189-210. Jakkoli latentně bude křest’anství provázet neustále, např. v českém křest̉anském prostředí narazíme dle mé zkušenosti na gnózi kdekoli spustíme sondu, bez ohledu na konfesi či duchovní proud v rámci určité konfese.

24 V rámci studia dynamiky tradice se v mém týmu na TF snažíme o porozumění otevřenosti Staré církve okolním kulturám. 
přijímání i odevzdávání podnětů. Jedině v tomto pozitivním smyslu cituji následující mínění:

Zůstalo až podnes otázkou, zda zcírkevnění bylo pro křest’anství přiměřenou cestou. Co mluví proti ,justinovskému“ křestanství, jež je otevřeno diskursu a nabízí se společnosti jako přispění k všeobecnému zprostředkování hodnot? Vždyṫ velké německé konfese již tuto argumentaci do značné míry převzaly. Co mluví proti „valentinovskému“ spekulativnímu křestanství, podněcujícímu náboženskou fantazii a chtějícímu mluvit o vzdáleném Bohu pomocí kombinace obrazů? Vždyt velká část nabídky církevních vzdělávacích center se již zabývá právě tím. Proti etizaci a estetizaci křestanství mluví podle mého názoru právě systemicko-teoretický argument, totiž vztah mezi náboženským systémem jako celkem všech kódovaných komunikací a náboženskou organizací jako celkem všech komunikací závislých na rozhodování. Zjevně nebylo možné udržet bez organizace hranici náboženského systému a zabránit rozplynutí v jiných systémech, jako je morálka a umění. Kde se pouze diferencují rity a role, ale chybí instituce a kanonizace, hrozí trvale inflace směrem dovnitř a difuze směrem navenek. Kde náboženství nevnímá samo sebe současně zvenčí, může sklouznout do jiné funkce, aniž to zpozoruje. Náboženská znamení se užívají dál, ale nikdo už vlastně neví proč. (...) Existuje tedy interdependence mezi sebedefinicí navenek (vůči ne-náboženství) a sebedefinicí dovnitř (vưči falešnému náboženství). ${ }^{25}$

Doplňuji, že tato interdependence pak logicky existuje i mezi odmítáním jedné a druhé sebedefinice.

\section{REDESKRIPCE KLASICKÉ TRINITÁRNÍ TEOLOGIE A CHRISTOLOGIE}

BEZ THEISMU?

Luhmann vrací do diskuse figuru paradoxu, jakkoli jde u něj často spíše o rétorické paradoxy než o paradoxy v podstatě věci, a jakkoli kolísá mezi striktním pojetím paradoxu jako nezrušitelného a zrušením paradoxu jeho rozložením. ${ }^{26}$ Paradox byl v patristické, zejména východní teologii podstatnou figurou, a je i v teologii Lutherově (a např. Kierkegaardově). Kloním se k interpretaci, že je třeba - přinejmenším

HAFNer, Häresiefähigkeit, s. 209n.

Toto „odparadoxování“ by pak mělo být podle Luhmanna charakteristické pro náboženství. Charakter Luhmannových paradoxů zkoumá Philipp STOLlger, „Kommunikation von Paradoxen: Zu Luhmanns Umgang mit Paradoxen und den anschliessenden Möglichkeiten für die Theologie," in Luhmann und die Theologie, ed. G. Тномаs - A. Scнüle, Darmstadt: Wissenschaftliche Buchgesellschaft, 2006, s. 67-92. 
v teologii - akcentovat nezrušitelnost paradoxu a dynamiku rozkládání paradoxu vidět jako principiálně neukončitelnou dynamiku křest’anství: Nejde o rétorickou figuru, ale o jedinou možnost našeho př́istupu k určitým věcem, které jsou vlastním předmětem teologie.

Základním paradoxem v Luhmannově koncepci systému je paradoxní jednota obou stran kódu. Kód systému „náboženství" se však podle Luhmanna ${ }^{27}$ od ostatních kódů liší tím, že je definován právě druhou, negativní stranou, a proto narozdíl od jiných kódů, které vylučují vše, co je na druhé straně rozlišení, náboženský kód právě tuto druhou stranu rozlišení nevylučuje, ale zahrnuje. Odtud pak plyne i zcela jiný způsob argumentace: „V př́padě náboženství lze zdůvodnění dosáhnout nikoli vyloučením, ale jen zahrnutím protihodnoty, nikoli jako pravdu vyloučením nepravdy, ale novým oceněním všech rozlišení v transcendentním dání smyslu. “" ${ }^{28}$ Epochu vzniku křestanství a raného (či pozdního) judaismu vidí Luhmann jako dosažení podstatně nového vývojového stupně náboženského kódování. ${ }^{29}$ Je pozoruhodné, že, ač sociolog, nevidí Luhmann žádnou bezprostřední souvislost mezi formou společnosti a formou náboženství a přiznává náboženství autonomní vývoj - a je to právě binární kód, co zaručuje vnitřní konsistenci náboženství v jeho vymezení vůči společnosti. Starnitzke z toho vyvozuje: „Pokud bychom chtěli pojmout do teologie tyto Luhmannovy myšlenky, pak by právě i aktuálně šlo o stupňování nezávislosti teologie na společenských trendech. Nikoli vztah k aktuálním společenským požadavkům a bezprostřední přebírání společenských změn a vymezování problémů by pak bylo primárním teologickým úkolem, ale co možná nejsvébytnější rozvíjení teologických modelù, které jsou k dispozici. Této systemickoteoretické směrnice je jistě třeba dbát tam, kde se teologie orientuje více podle společenských trendů než podle svých nejvlastnějších vymezení otázek a pojmů. ${ }^{130}$

Luhmann, Die Religion der Gesellschaft, s. 22.

Tamtéž, s. 91.

29 Tamtéž, s. 90.

30 Dierk StarnitzKe, „Die binäre Codierung der Religion aus theologisch-exegetischer Sicht," in Luhmann und die Theologie, ed. G. Tномаs - A. Scнüle, Darmstadt: Wissenschaftliche Buchgesellschaft, 2006, s. 173-188. V návaznosti na své studie o apoštolu Pavlovi doporučuje Starnitzke profilovat křest’anství v moderní společnosti rozvíjením konceptů obsažených v Písmu svatém. Sám Luhmann ovšem vidí vztah náboženství a světa diferencovaněji, „dialektičtěji“: „Náboženství je možno vidět jako strukturu, díky které lze zvládnout (abfangen) tlak na variace tím, že se náboženství zčásti přizpů- 
Podle Luhmana „Dogma o vtěleném Bohu umožňuje podržet rozlišení transcendence/imanence, zanechává však problém, jak lze ze setkání s Ježíšem usuzovat na Boha". ${ }^{11}$ To je otázkou prvních křestanských staletí, i Luhmann však konstatuje: „Transcendentního Boha je třeba si představovat jako nerozlišeného, ale současně jako rozlišitelného ve formě Krista. "32 Dierk Starnitzke, o jehož interpretaci se v tomto odstavci opírám, ${ }^{33}$ soudí, že tato konstelace dává křestanství jeho formu. Přitom si Luhmann všímá, že křestanství umožňuje myslet Boha jako všudypřítomného a vždypř́itomného a současně vnímat privilegované a neopakovatelné okamžiky zjevení (tj. rozlišit čas a dějiny/věčnost). Privilegovanými okamžiky jsou pro křestanství zvláště Ježíšuo život, smrt a vzkř́ŕšení a jeho zjevení určitým osobám. Pozdně-židovská, v křest’anství modifikovaná koncepce Stvořitele umožňuje myslet současně jednotu a komplexnost a Boha jako nad světem i přítomného světu, a v křestanství pak obojí vztáhnout ke Kristu. V židovsko-křest’anské tradici lze proto podle Luhmanna tematizovat Boha $\mathrm{v}$ diferenci imanentní/transcendentní, a sice jako reflexi jednoty kódu. ${ }^{34}$ Boha tedy není nutno lokalizovat jen na stranu transcendence, ale je možné a potřebné teologicky zkoumat jeho působení na straně imanence.

Luhmann vychází celkem bezproblematicky z toho, že křest’anství je monoteistické náboženství, což Starnitzke považuje za zjednodušující už pro židovství. ${ }^{35}$ To vede $\mathrm{v}$ Luhmannově koncepci k problémům diference a možnosti udržení její jednoty. Starnitzke ovšem ukazuje, že v křestanství tento problém takto vyhroceně nevzniká, protože jednota kódu, a tím i sebepopis křestanství, nevychází primárně z transcendentního Boha, ale především z Ježíše Krista: „Charakter křest’anské víry spočívá právě v tom, že na jedné straně Bůh zásadně lokalizovaný v transcendenci a na druhé straně vlastní zkušenost se světem jsou v Ježíši Kristu reflektovány ve své jednotě. Obě strany rozlišení imanence/transcendence drží pohromadě především christologie" (Starnizke, s. 184). Prá-

sobí a zčásti tento tlak odmítne, a tím nabývá strukturu rozhodování, která může zpracovat větší plnost variací" (LuHmann, Einführung in die Theorie der Gesellschaft, s. 206).

Luhmann, Die Religion der Gesellschaft, s. 134.

Tamtéž, s. 125.

Starnitzke, Die binäre Codierung der Religion aus theologisch-exegetischer Sicht, s. 173188.

Ponecháváme zde stranou Luhmannovu koncepci formule kontingence.

A vzhledem k současné filosofické kritice monoteismu a islámského zpochybňování křestanství jako skutečně monoteistického náboženství mu asi rádi dáme za pravdu; jinak ovšem soudí Oberdorfer, viz dále. 
vě ze zaměření na christologii pak plyne (proti Luhmannovi), že Bůh je v křestanství reflektován především na "této straně“ kódu (s. 185). Logos a Bủh jsou radikálně rozlišeni a současně Logos radikálně participuje na božství Boha. Proto také může Tomáš vyznat „Pán můj a Bůh můj” právě při pohledu na rány Vzkříšeného. „Je proto nutné být skeptický vưči tezi, že se, zvláště v př́ípadě raného křestanství novozákonní doby, jedná o monoteistické náboženství, které jednotu svého kódu reflektuje pouze pomocí formule kontingence ,Bůh'. Spíše by bylo možno formulovat teologicky přesněji: Křestanská náboženská komunikace se vyznačuje právě tím, že jediný Bůh v ní musí být chápán prostřednictvím této transcendentnosti a imanentnosti Ježíše Krista zcela nově, totiž jako radikálně transcendentni" (s. 187). Formule "Ježíš Kristus" je tímto dvoj-označením toho, v co, resp. koho křestanství věří, přičemž jméno „Ježíš" označuje imanentní stránku, tedy to z Boží skutečnosti, co se věřícímu otevírá v rámci tohoto světa, a titul „Kristus“ označuje to, co zásadně překračuje jakoukoli vazbu víry na imanentní jevy a osoby. „Pro křestanství je tedy konstitutivní nikoli primárně vztah k jedinému Bohu, ale reflexe jednoty imanence a transcendence v Ježíši Kristu. Tato figura myšlení a víry, a nikoli, jak míní Luhmann, závazek vůči jedinému Bohu (tj. monoteismu, pozn. J. V.), byla tím, co dalo křestanství centrální orientaci, která mu dovolila při vší pluralitě teologických konceptů rozvinout jediný uzavřený systém“" (s. 187). Binární kódování vázané na monoteismus by takový prostor pro pluralitu nikdy nemohlo nabídnout, a není tedy ani právo vývoji raného křestanství.

Analýza komunikace Boha člověku, tedy komunikativní přítomnost Boha ve stvořeném, kterou provedl Günther Thomas, ${ }^{36}$ ukazuje podobným směrem. Thomasovým tématem je Boží zjevení jako proces komunikace vycházející v křest’anském pojetí od Boha. Thomas je přesvědčen, že vhodným nástrojem pro analýzu je Luhmannova teorie komunikace a zvláště figura re-entry. ${ }^{37} \mathrm{~V}$ návaznosti na Spencera-Browna soudil Luhmann, že jakékoli pozorování je provedením rozlišení, při němž je označena pouze jedna strana označeného, a tím učiněna předmětem po-

36 G. Thомаs, „Kommunikation des Evangeliums - oder: Offenbarung als Re-entry, in Luhmann und die Theologie," in Luhmann und die Theologie, ed. G. Tномаs - A. Scнüle, Darmstadt: Wissenschaftliche Buchgesellschaft, 2006, s. 15-32.

37 K pojmu re-entry u Luhmanna viz např. N. Luhmann, Einführung in die Systemtheorie, Heidelberg: Auer, 2011, s. 77nn. a z teologického hlediska zvláště s. 161, kde Luhmann ř́ká: „Těmito úvahami, pokud je uvedeme do obecné formy, je opět navozeno téma re-entry: Pozorovatel opět vstupuje do toho, co pozoruje." 
zorování. ${ }^{38}$ První rozlišení odliší systém a všechno ostatní, toto rozlišení - a to je podstatou re-entry - může pak být znovu aplikováno v rámci rozlišeného systému. Teologicky to znamená, že rozlišení transcendence a imanence je pak ještě možno znovu aplikovat v imanenci jakožto nám přístupné straně rozlišení. Zatímco Luhmann je ve své akcentuaci Boží nerozlišitelnosti blíže mlčení mystiků a reformované teologii s jejím „finitum non capax infinitum“(sic!), Thomas soudí, že jako re-entry lze popsat mnohé procesy křestanské tradice, kdy sice bylo uchováno rozlišení imanence/transcendence, ale různé sféry imanence se stávaly médiem transcendence. V křest̉anské tradici je tomu ovšem tak, že událost re-entry je pojata jako sdělení, přičemž je Bůh tím, kdo sdílením jedná, a člověk tím, kdo sdělení "zažije“. Podstatné je, že Bůh neprovádí reentry na své straně, ale na straně od něho odlišené. ${ }^{39}$

Re-entry nemusí být jednorázovou událostí, pro židovsko-křestanskou tradici jde o proces - a nejen pro religionistu, ale i pro teologa je dle Thomase zajímavé pozorovat, které oblasti, funkce a jiné aspekty stvořeného jsou do tohoto procesu selektivně zahrnuty - přičemž zřejmě logikou selekce není jen vývoj systému, ale i sociokulturní prostředí. V rámci rozlišení nebes a země Bůh „přebývá“ v nebi (které však nesmí být zbožštěno), toto rozlišení se pak opakuje v přebývání v chrámu. Sebezpřítomnění (ač dar) zde nelze myslet bez sebeodepření a nedisponovatelnosti. Chrám je tedy opakováním rozlišení nebe a země na straně země. Nejústřednější a nepřekonatelnou Boží sebeimplikací je pro křest’anství bezpochyby příběh Ježíše Krista. Zde - soudí Thomas (s. 30) - dosáhlo Boží re-entry takové intenzity, takové míry pozorovatelné př́tomnosti v imanenci, jakou člověk vyhodnotil jako nesnesitelnou a násilně ji ukončil. „V Kristu postavil Bủh proti moci nepozorovatelnosti bezmoc pozorovatelnosti jako moc lásky“ (s. 30). Imanence je v Kristu současně místem přítomnosti, Bůh se v ní neskrývá, ale zjevuje. Rozlišení transcendentního a imanentního se tím neruší, ale stává se pozorovatelným.

38 První rozlišení přitom je v rámci systému nepozorovatelné a představuje jeho „slepou skvrnu“, může být rozlišeno pouze pozorováním druhého řádu, tedy „pozorováním pozorování". Např. rozlišení pravdivý/nepravdivý nelze v rámci pozorování prvního rádu aplikovat na toto rozlišení (a ptát se, zda je samo pravdivé) - to by znamenalo zablokování systému.

39 Thomas mluví luhmannovsky o Selbstimplikation v rozlišeném. Kapitolu Christologie als re-entry najdeme i v knize BlANKE, Systemtheoretische Beobachtungen der Theologie, s. 149-157. Blanke kupodivu Thomasův text necituje, ač se o sborníku, jehož je text součástí, vyjadřuje zlehčujícím způsobem, takže jej zná. Nic nového k němu nepřidává. 
Jednota kódu dle Thomase stačí k tomu, aby byl Kristus označen jako Syn Boží - bez potřeby ontologických kategorií. „V Kristu pozorovatelná jednota kódu je láska odvažující se do rizika" (s. 31). ${ }^{40}$

Ohledně monotheismu křest’anství, problematizovaného Starnitzkem, soudí Bernd Oberdorfer, ${ }^{41}$ že se křest̉anství přihlášením k Bohu Izraele přihlásilo ke striktnímu monotheismu, a že úkolem trojiční teologie právě bylo uvést trojici božských instancí do vztahu $\mathrm{k}$ fundamentální Boží jednotě. Právě trojiční pojetí Boha umožňuje proto monotheistickou koncepci stranou novověkého theismu, přičemž jednota zůstane konstitutivní. Luhmannovu "formuli kontingence“", tedy Boha, je ovšem nutno opravdu pojmout trojičně, pokud nemáme upadnout do problémů, do nichž upadl Luhmann, příznačně o Trojjedinosti prakticky všude mlčící. Trojiční a christologicko-inkarnační dogma je podle Oberdorfera pojmovou explikací elementární skutečnosti, že o Bohu lze mluvit pouze tak, že mluvíme o Ježíši Kristu, který se stal člověkem. Bůh v Kristu je v plnosti jednotou transcendence a imanence, protože toto pojetí Boha umožňuje integrovat i radikální opak rozlišujících atributů (tedy všemohoucnost a bezmoc, vševědoucnost a omezené vědomí, nekonečnost a konečnost, ubikvitu a lokálnost, nesmrtelnost a smrtelnost, dokonalost a nedokonalost - Oberdorfer připojuje i hřích, což by bylo ovšem potřeba dále diferencovat). Klasické christologické dogma zdůrazňuje, že tato jednota transcendence a imanence se děje, aniž jsou "přirozenosti“ slity v jedno, ale také, aniž pouze koexistují vedle sebe. „Bưh je v Kristu pozorovatelný, ale že je to Bůh, kdo se v člověku Ježíšovi autenticky zviditelňuje, je paradoxní výpověd' víry, protože božství je ,skryto pod protikladem' (Luther), totiž pod podobou konečného, zlu a zlobě pasivně vystaveného, ba jako rouhač popraveného člověka; ,přímé‘ pozorování Boha, které by chtělo obejít tuto okliku, není možné“ (s. 113). Vztah Otce a Syna je pozorovatelný, ovšem pouze tomu, komu to Bůh sám otevře, což je systemicko-teoreticky konformně vyjádřeno učením o božství Ducha svatého jako toho, kdo může pozorovat, že se Bůh vystavil pozorování a vzdal se své pozovatelské pozice, a komunikovat to lidem. Proto nikdo nemůže říci Kyrios Iesous, leč v Duchu svatém (1 Kor 12,3).

40 Za rámcem teologie zjevení by mohlo být přínosné aplikovat figuru re-entry i na otázku Písma a svátostí.

41 B. Oberdorfer, Kontingenzformel Gott, s. 114. 


\section{KTERÝ KóD?}

Identita křest’anství jako systému je zajištěna komunikací v křest’anském kódu, opakováním křestanského rozlišení. Luhmannův závěr, že podstatou náboženství je komunikace v kódu imanentní/transcendentní, ${ }^{42}$ je sice kritizován, ale současně i přijímán, a pokud jej budeme vidět v christologickém a inkarnačním kontextu, zdá se mi vyhovující i pro vyjádření identity křestanství. Otázkou k diskusi ovšem zůstává operacionalizace tohoto kódu, tedy to, co Luhmann nazývá sekundárním kódováním (Zweitcodierung).

Řekl bych, že si s problémem neví rady ani sám Luhmann. Brání se, aby kódování kopírovalo kód morálky (dobré/špatné jednání), a sice jednak $\mathrm{z}$ důvodu své obecné rezervovanosti vůči morálce, ${ }^{43}$ jednak z vlastních důvodů své teorie, protože morálka je v rámci moderní diferenciace společnosti samostatným a na náboženství už nezávislým systémem (s problémy, které pro ni z této "sekularizace“ plynou). Protože v českém prostředí mnoha křest’anům křestanské splývá s morálním a uniká jim existence morálek na křest̉anství nezávislých, a protože řada křestanů vidí společenskou roli křestanství právě v moralizaci společnosti (viz podobně citát výše o německém prostředí), je třeba se u této možnosti kódování zamyslet. Luhmann sám upozorňuje na fatálnost takové pozice: Zatímco ve středověku určovalo náboženství morálku, v novověku se z morálky stalo nadřazené kritérium pro posuzování přijatelnosti náboženství (jako celku i jeho dílčích prvků). Právě postmoderní znejistění v oblasti morálních principo̊ (kterým se Luhmann ještě nemusel zabývat) zpochybňuje náš častý předpoklad, že morálka je tím, o čem jsme schopni se s ostatními dorozumět, zatímco věrouka je sporná - předpo-

42 Jakkoli se toto kódování liší od kódování ostatních systémů, zejména tím, že pravá, tj. negativní strana kódu má pro náboženství naopak vysoce pozitivní hodnotu.

43 K Luhmannově rezervovanosti vůči morálce srov. např. jeho známý bonmot, že „Vzhledem $\mathrm{k}$ tomuto stavu věcí je snad nejnaléhavějším úkolem etiky varovat před morálkou“ (N. Luhmann, Die Moral der Gesellschaft, Frankfurt am Main: Suhrkamp, 2012, s. 266.) Ve studii „Die Ausdifferenzierung der Religion,“ která náboženství analyzuje zvláště ve vztahu k morálce, Luhmann soudí, že skutečné poznání je „blokováno tam, kde náboženství trvá na morálním kódování svého programu a nevidí žádnou jinou možnost, jak operacionalizovat kód transcendence/imanence“. Církev podle Luhmanna nejprve dobře strávila zapovězené ovoce (poznání dobrého a zlého), ale nyní by si měla uložit zdrženlivost při kázání morálky. (LuHMANn, Gesellschaftsstruktur und Semantik, s. 335n.) 
klad typický pro evangelický liberalismus, ale sdílený i mnohými katolíky. Samozřejmě je v rámci systemické teorie myslitelné, že náboženství po diferenciaci od morálky provede interně re-entry tohoto rozlišení, což se ostatně stalo v podobě evangelických křestanských etik či katolických morálních teologií - je však otázkou, zda je to dobré i z hlediska křestanství. Ve zmíněné diskusi na téma „křest’anství jako náboženství" formuloval kdysi Vladimír Boublík kompromisně, že křestanství je nový život v Kristu, který má v tomto světě podobu náboženství. Binární kód nový život v Kristu/starý život by podle mého soudu mohl být - po připuštění, že tu je křestanství společensky přítomno jako náboženství - operativním kódem křestanství.

Jakkoli nový je pohled systemické teorie, pohled do Nového zákona ukazuje, že tu je toto binární kódování od počátku př́tomno. Binaritu kódu Janova evangelia není třeba dokládat, nového ocenění by se naproti tomu mohlo dostat kódování apoštola Pavla - nový/starý člověk, nové/staré stvoření, kata pneuma/kata sarka aj. Z křest’anské tradice tu jsou pojmy jako následování Krista (imitatio Christi, theosis). Z modernějších koncepcí by bylo zřejmě možné vyjít z formulací jako ,ježíšovský“ či „christoformní“. Je-li dynamika systému v reprodukci určitého typu komunikace, pak by bylo možné formulovat kód na základě evangelií jako „reprodukci komunikace Kristovy“ (následování Krista a apoštolů). To jsou jen zkusmé návrhy, protože takový kód musí splňovat celou řadu dalších kritérií, zejména musí formovat praxi, nikoli ji postulovat či normovat od teologova počítače. Navíc jsem si vědom, že většina pojmů, které jsem uvedl, je poznamenána individualistickou koncepcí zbožnosti, zatímco operativní kód by musel fungovat současně jako kód společenství (pro církevní jednání). Samozřejmě by bylo možno kódovat, a prakticky se asi mnohdy kóduje, v relaci hřích/nehřích, ale to by mohlo být adekvátní pouze tam, kde hřích není pojat moralisticky, a navíc je tím křest’anské jednání vymezeno negativně - nehřešit ještě neznamená žít křest’ansky. ${ }^{44}$

44 Dierk Starnitzke, který sledoval kódování v rámci Nového zákona, mi k tomu soukromě vyjádřil názor, že kódování transcendentní/imanentní považuje pro křestaanství za dostatečné, protože Boží milost a odpuštění zahrnuje i hříšníka s jeho hříchem. Ale i on vidí, že z přijetí milosti plyne nový život, který je dle něho dostatečně kódován přikázáním lásky. 
Luhmann sám se zamýšlí nad tradičním kódem vztaženým k poslednímu soudu a jeho binárnímu vyznění: věčný život a věčné zavržení. ${ }^{45}$ Teologicky ani jinak jej nehodnotí, jen konstatuje, že tento kód byl fakticky v mainstreamovém křestanství opuštěn (v souvislosti s přechodem k inkluzivnímu postoji) a nebyl ničím adekvátním nahrazen. ${ }^{46}$ Problém spočivá zřejmě v tom, že tento kód teoreticky opustit nemůžeme, jakkoli jsme ho zřejmě tiše opustili prakticky - operativním kódem je v každém případě okrajově, spíše v prostředí fundamentalistických uskupení.

Ani Luhmann ovšem pozitivně nic schůdného nenavrhuje, resp. jeho návrh kódu „reagovat na pozitivní i negativní zkušenost postulováním pozitivního smyslu“ (což by prý měl být minimální kód vystihující komunikaci v náboženském modu) se zjevně hodí spíše pro kurzy pozitivního myšlení než pro křestianství. Samozřejmě bychom mu mohli dát i podobu kódu „díkůvzdání jako reakce na pozitivní zkušenost/prosba o odpuštění a přímluva jako reakce na negativní zkušenost", ale takový kód by zjevně nepostihoval celek křestanského života. Mohl by ovšem být kódem modlitby jednotlivce i modlitby společenství. Větě, která pak v Luhmannově textu zanedlouho následuje jako součást výkladu o pozitivním smyslu negativního, však jistě lze dát i dobrý teologický smysl: „I to pozitivní (...) musí být ve světle transcendence hodnoceno jinak než imanentně, aby kód získal vztah ke světu a mohl se jej držet." ${ }^{47}$

Kandidátem na kód samožrejmě mohou být i obecná kritéria teologické práce, ale u těch se zdá, že nějak selhávají v současných diskusích $^{48}$ - kód v systemické teorii slouží pokračování komunikace, nikoli její neutralizaci či blokaci. Jakkoli je to absurdní, na komunikaci v kódu biblické/nebiblické se dnes neshodneme ani v rámci konfesijních společenství.

45 A sice přímo komentářem k perikopě o posledním soudu, srov. LuHMANn, Gesellschaftsstruktur und Semantik, s. 294nn.

46 To se týká i oficiálního římského katolictví: Když stoupenci reformních alternativ svého času kritizovali, že pro oficiální církev se z Frohbotschaft stala Drohbotschaft, dostalo se jim překvapivé odpovědi, že v kázáních tehdejšího papeže (Jana Pavla II.) se motiv pekla vůbec nevyskytuje. Striktně viděno, ani z římskokatolického hlediska nikdy nebyl strach ze zavržení dostatečnou motivací pro křest’anské jednání.

47 Luhmann, Gesellschaftsstruktur und Semantik, s. 352.

48 Např. kód „podle Písma/v rozporu s Písmem“ či kód „ve shodě s duchem křestanství/v rozporu s ním". 


\section{LZE NA LUHMANNOVĚ TEORII VYBUDOVAT TEOLOGICKÝ SYSTÉM?}

Výše uvedené christologické a trinitární náběhy vedou k otázce, zda jde o invence ad hoc či zda lze na Luhmannově teorii vybudovat regulérní teologickou, či alespoň systematicko-teologickou koncepci. Disertaci pokoušející se o reinterpretaci teologie v Luhmannově duchu s cílem vytvořit komplexní teologický systém pro informační věk obhájil v Princetonu již v r. 2006 Young Bin Moon, což by svědčilo pro tuto možnost; její knižní vydání však ohlásilo nakladatelství Siebeck-Mohr už na r. 2010, ale stále ji nevydalo, a na můj dotaz, kdy ji konečně vydá, odpovědělo, že i př́ští ohlášený termín nebude dodržen - to se zdá svědčit proti možnosti takovouto teologii předložit.

Problém s možnou aplikací Luhmannovy teorie na teologická témata mají i jiní. Např. Dallmann píše: „Vyřešil by se tím sice problém Boží nepozorovatelnosti, ale za cenu, že by bylo nutno reformulovat všechny historické obsahy teologie a víry. Zda by za těchto okolností bylo ještě možné uchovat zvláštní charakter křest’anské víry, je otázkou. Luhmannovská ,záchrana' víry (doporučovaná ve Funktion der Religion, s. 59n. a 175nn, pozn. J. V.) by pak znamenala její sebelikvidaci." ${ }^{49}$ Eberhard Blanke, mluvčí EKD, cituje tento výrok, ale na rozdíl od ostatních teologů, kteří prý zde couvli, jej chápe jako výzvu k reformulování obsahů - bez toho prý všechna teologie zůstane stále předvědecká. Z Moonova pokusu máme zatím $\mathrm{k}$ dispozici jen úryvek z trinitární části, otištěný $\mathrm{v}$ časopise Zygon, ${ }^{50}$ nicméně můj závěr $z$ něj je, že Luhmanna lze aplikovat i bez teologické sebelikvidace. Blanke zjevně nechápe obecné principy aplikace převzetí určitého konceptu jinou odbornou disciplínou (které vždy znamená modifikace a selekce), jakož ani obecné principy převzetí sekulární koncepce teologií (které znamená totéž, navíc důsledně „or todoxni" převzetí konceptu, hájené Blankem, vede prakticky vždy $\mathrm{k}$ heterodoxii). Moonův pokus, který se pokusím dále stručně představit, je selektivním a modifikovaným převzetím koncepce, a tam, kde se mi jeví jako heterodoxní, neplyne to dle mého soudu z logiky Luhman-

49 H.-U. Dallmann, „Immanenz, Transzendenz, Kontingenz, in Niklas Luhmanns Denken: interdisziplinäre Einflüsse und Wirkungen, ed. H. Gripp-Hagelstange, Konstanz: UVK, Univ.-Verl. Konstanz, 2000., cit. podle Blanke, Systemtheoretische Beobachtungen der Theologie, s. 30.

50 Y. B. Moon, "God as a Communicative System sui generis: Beyond the Psychic, Social, Process Models of the Trinity," Zygon 45 (2010): 105-126. 
novy teorie, ale spíše z ohledi̊ na určitý proud teologické diskuse, v níž se některá tvrzení jeví jako nepřijatelná.

Moonův pokus o "media theology" založenou na Luhmannovi představuje "teologickou extenzi Luhmannova paradigmatu“ (s. 106), navazující ovšem na Luhmannovy úvahy o Bohu jako komunikaci a Bohu jako pozorovateli/stvořiteli. Za hranice Luhmanna jde i v tom, že Luhmannův přístup byl instrumentalistický: Bůh je pro něj čirý koncept, nicméně důležitý ve své sociologické funkci pro sociologa i pro celou společnost. Naproti tomu teologická extenze se nemůže vyhnout metafyzickým a epistemologickým úvahám - z tohoto hlediska chápe Moon svou pozici jako realistický operativní konstruktivismus a funkcionalismus. S Luhmannem sdílí Moon rozchod s klasickou metafyzikou a ontologií a Luhmannovu pozici označuje jako postmetafyzický operativní realismus, kdy ontologické hledisko je sice suspendováno, ale pozorování a konstruování jsou považovány za reálné operace. To, co tedy Luhmann připouštěl pro společenské systémy, ale nikoli pro Boha (tj. realistický pohled), to Moon rozšiřuje i na Boha a k Luhmannovým čtyřem systémům - mechanický, organický, psychický a sociální - přidává ještě božský systém. V následujícím textu pak zvažuje, nakolik to takto rozšírit lze a co se tím získá. Tím chce naplnit někdejší Greenův požadavek vytvořit teologickou teorii systémů. Rozlišuje ovšem božskou realitu, nám nedostupnou, a realitu konstruovanou pomocí pojmů komunikace a pozorování. Tato konstrukce ovšem není svévolná, ale neredukovatelně emergující ${ }^{51}$ Moon nekonstruuje svou koncepci čistě z Luhmannovy teorie, ale z napětí mezi ní a teologickou tradicí (s. 110). Luhmannova teorie je pro něj formálním a teologická tradice materiálním zdrojem. Metodou je respecifikace obecné teorie pro zkoumaný specifický systém (teologický, resp. božský).

Moon vychází z Luhmannových konceptuálních úvah o Bohu jako pozorovateli, což je u Luhmanna vztaženo ke creatio continua a k vševidoucnosti/vševědoucnosti. Nad Luhmannovy výroky, ale v logice jeho teorie, Moon vidí Boha nejen jako pozorovatele jiných, ale i jako sebe-pozorovatele. Věčnou božskou distinkcí je u Boha věčné vyloučení nicoty jako distinktivní božská operace vylučující nejsoucí a nebožské, tj. svět. Vyloučené není ničím, na čem by tak Bůh byl závislý, jde pouze o potenciální-virtuální akt, který se stvořením světa stává aktuálním. Až

51 Moon se odvolává na Luhmanův termín Eigenvalue převzatý z kvantové fyziky. 
stvořením se stává aktuální i předtím virtuální dimenze času, Bůh sám je transtemporální. Formou božské operace je ve shodě s biblickou tradicí komunikace, která má význam..$^{52}$ Božskou operací je primárně mluvení, a tato operace je od něj neoddělitelná - Boží operace je Slovo u Boha, Bůh je komunikace. S lidskou komunikací je tu podobnost v realitě komunikace, a nepodobnost ve způsobu komunikace. Citován je zde i jinde Barth s pojetím, že Boží mluvení je sui generis, odlišné od každého jiného mluvení. Božskými kvalitami jsou nepřekročitelná komplexnost, nekontingentnost, supratemporální autopoiesis a komunikace ad intra, která je však propojena s komunikací ad extra. Význam označuje jednotu aktualizace a virtualizace, reaktualizace a revirtualizace zkušenosti a jednání. Lidská zkušenost je aktualizací z rezervoáru možných zkušeností. V př́ipadě Boha se realizuje nekonečný horizont komunikativních možností či nevyčerpatelný zdroj významu, Luhmannem postulovaný i pro sociální systémy. Bůh je $\mathrm{v}$ tomto smyslu nekonečně komplexn ${ }^{53}$ a s nekonečnou možností výběru (Boží svoboda), je základem všech systémů komunikace a významu. Boží autopoiesis je dokonalá a možnosti tvoření komunikativních událostí nevyčerpatelné. Bůh je plně aktuální a nekonečně potenciální.

Jako symbolické médium v Luhmannově smyslu vidí Moon lásku (s. 116n). Zde se ovšem obrací k biblické tradici, která zná i jiná média - uvádí dále milost, spravedlnost, pokoj a osvobození, a na jiném místě připojuje ještě moudrost, život, pravdu. Jako tradičně dominující hledisko vidí lásku, také s odvoláním na inkarnaci a kř́žž, a na slova „Bůh je láska“ (1 Jan 4,8.16). Ale i Luhmann, připomíná Moon, píše, že podle tradice sahající až do dnešních dnů je způsobem Božího pozorování láska. Láska u Luhmanna není cit, ale symbolické médium intimního vztahu. ${ }^{54}$ „Bůh je perfektním systémem interpenetrace prostřednictvím symbolického média láska“ (s. 117). Láska je mocí plodící nekonečné komunikace, milující nemưže přestat komunikovat - v božském systému to platí o lásce nekonečně pravdivě, protože zde jsou možnosti komunikace a významu nevyčerpatelné. Láska je materiálním zdrojem nekonečné komplexity božské komunikace a věčná autopoiesis Boží. Ve vztahu k nekonečné

52 Jakožto meaning překládá Moon termín Sinn, převzatý Luhmannem od Husserla.

53 Moon parafrázuje Anselma: Nad něhož větší komplexnost nelze myslet - Moon soudí, že Bůh může překročit i vlastní komplexitu - ta je ovšem nikoli jen srovnatelně nejkomplexnější, ale je komplexitou sui generis.

54 Symbolickým médiem se v teorii systémů rozumí nositel významu. 
komplexnosti a selektivitě systému láska znamená, že komplexita ani selektivita není arbitrární, ale strukturovaná a podmiňovaná láskou.

Až potud je asi možné s Moonem vcelku souhlasit (pokud principiálně neodmítáme konstruktivistický př́istup). Rozpaky asi vzbudí jeho explikace interního pozorování a komunikace v Bohu. Na jedné straně je patrné, že Moonův Bůh musí být trojičně komunikujícím společenstvím (s ohledem na tři prvky komunikačního modelu), na druhé straně Moon výslovně ŕíká, že "these traditional trinitarian symbols are used here only for the sake of convenience - they can by replaced by other symbols, including feminist ones". Jinak se ale opírá i zde hlavně o Bartha, ${ }^{55}$ včetně obhajoby Filioque. V komunikativním modelu je Otec odesílajícím, Syn kódujícím, Duch dekódujícím - tak tomu asi opravdu je ve zjevení lidem, ale je otázkou, nakolik to má smysl postulovat pro intratrinitární komunikaci. Ta je u Moona překvapivě zcela neosobní. Luhmann ovšem důsledně odděluje komunikativní systémy od psychických systémů, ale jelikož Moon nikde necituje Luhmannův výklad v Die Wissenschaft der Gesellschaft, ${ }^{56}$ mám podezření, že tento text Moonovi unikl - právě v něm ovšem Luhmann pojem personae do modelu komunikace zavádí!

\section{ZÁvĚreČNÉ OTÁZKY}

Obecná otázka vhodnosti Luhmannovy teorie pro teologii se v českém prostředí klade ještě jako otázka její vhodnosti v českém prostředí. $\mathrm{V}$ tomto textu jsem se pokusil naznačit diskuse $\mathrm{v}$ české teologii, kterých se Luhmannovo dílo dotýká. Je samozřejmě otázkou, nakolik

55 Vztah teologických navázání na Luhmanna k Barthovi by stál za samostatné zkoumání, které ponechávám na někom kompetentnějším v Barthově teologii. Určitou pozornost věnuje této otázce ve své frankfurtské disertaci R. DAHnelt, Funktion und Gottesbegriff: der Einfluss der Religionssoziologie auf die Theologie am Beispiel von Niklas Luhmann und Falk Wagner, Leipzig: Evangelische Verlagsanstalt, 2009. Luhmann odmítá zahrnout do náboženského systému subjektivitu a zkušenost a zahrnuje teologii výhradně do náboženského systému, nikoli do systému vědy. DAhnelt (s. 88) cituje T. Rendtorffa, podle nějž se ve sporu Luhmann/Habermas opakuje analogicky spor Hegel/ Schleiermacher (Gotteslehre stricte dictu versus její osvojení individuálním subjektem), přičemž Schleiermacherově pozici odpovídá Habermasova.

56 Srov. N. Luhmann, Die Wissenschaft der Gesellschaft, Frankfurt am Main: Suhrkamp, 1992, s. 33n.: „Zvláštní konstrukce personality je tedy plně kompatibilní se zde hájenou tezí radikálního oddělení systémů." 
naše spíše dialogicko-personalistické prostředí může takto abstraktní a konstruktivisticko-funkcionální přístup přijmout - jako dialogický personalista se domnívám, že je to možné právě přes komunikativní model, méně přes model systémů. Bez problémů bude zřejmě přijata Luhmannova snaha obejít se bez metafyziky a ontologie. Jeho př́stup se ovšem může jevit jako funkční analogie k oběma odmítnutým př́stupům: ontologická otázka je sice dána do závorek, ale jinak je jeho teorie v lecčems analogická - zrcadlově opačně - scholastickým přístupưm - dưraz na diferenci funkčně supluje dưraz na substance, statičnost je nahrazena dynamickou realitou, teologická analogie má podobu analogie systémů či analogia operationis resp. communicationis. Na druhé straně je české teologické prostředí otevřené Husserlovým vlivům, kterými byl formován i Luhmann. Nepochopením (způsobeným zřejmě mou zjednodušující interpretací) by bylo obrátit proti Luhmannovi barthiánskou kritiku analogia entis a přirozené teologie. Překážkou přijetí může být i Moonova distance od Moltmanna, v českém prostředí obvykle ceněného - sociální model Trojice vidí Moon jako inklinující k tritheismu. Vítána naopak by mohla být jeho koncepce jako alternativa k procesuální teologii, k níž má Moon blízko, ale jejímž některým problematickým důsledkům se snaží vyhnout. Jeho Bůh je jistě Deus semper maior, ale při vší dynamice a potencialitě komunikace už jím aktuálně je. A pochopitelně - nám z generací vychovávaných barthiány - nabízí Luhmann možnost ponechat si své dobré vychování (svrchovanost teologického a vyznavačského systému) a současně se otevřít okolnímu prostředí (a historickému času), čerpat z něj a něco mu odevzdávat i jako teologové.

Zda se podaří vytvořit na luhmannovském základě teologický systém, nechme otevřené - Luhmann sám byl k vědeckým predikcím skeptický. Soudím, že tento přístup je vhodný tam, kde si neklademe otázky, na něž adekvátně může odpovědět pouze ontologie. Luhmann přece stále opakuje, že jeho teorie neodpovídá na otázku Co?, ale na otázku Jak? Tam, kde nás zajímá, jak věci „fungujï“ (jakkoli nepersonalisticky to zní, mluvíme-li o lidských a božských věcech), tam, kde nás zajímá dynamika systému, je Luhmannova teorie dobrým instrumentem. Sám ji užívám jako nástroj pro zkoumání dynamiky tradice ${ }^{57}$, ale také pouze jako jeden z nástrojů. Pokud si teologie nečiní větší nárok než konstruovat teologické modely (a nesnaží se dotknout esencí), zdá se Luhmannova 
teorie dobrým nástrojem. Jako alternativu k ontologii ji nevidím, spíše jako možnost rozvinout dynamickou dimenzi vedle větší či menší statičnosti ontologií, které máme k dispozici, ale nikoli alternativně, nýbrž komplementárně. Jakožto výzva naší teologii, luhmannovsky řečeno jako provokace a iritace našich systémů, je však Luhmann zjevně inspirativní.

\section{Luhmann - Protreptikos pros theologous}

Key words: Niklas Luhmann; open church; Christianity as religion; non-metaphysical models of theology; Trinitarian theology; Christology; code of systems

Abstract: The writer of this study reveals the connection between Luhmann's works and Czech theological discourse. He also demonstrates that the theory of systems provides new views on questions such as the open church, Christianity as a religion, non-ontological and non-metaphysical models of theology, and even the possibility of finding new formulations of Trinitarian theology and Christology. The author additionally considers the possibility of an application of Luhmann's notion of coding as an expression of the identity of a system. He also evaluates a possible formulation of the code of Christianity.

Doc. Mgr. Jaroslav Vokoun, Th.D. Katedra filosofie a religionistiky TF JU Kněžská 8

37001 České Budějovice 